\title{
PELATIHAN MENGAJAR DAN MENULIS LAPORAN HASIL BELAJAR DALAM BAHASA INGGRIS UNTUK GURU SMP/SMA TUMBUH YOGYAKARTA
}

\author{
Adaninggar Septi Subekti*, Arida Susyetina \\ Program Studi Pendidikan Bahasa Inggris, Fakultas Kependidikan dan Humaniora \\ Universitas Kristen Duta Wacana, Yogyakarta \\ email: adaninggar@staff.ukdw.ac.id
}

\begin{abstract}
This community service activity aims to provide English language training for teachers of Tumbuh High School, Yogyakarta, Indonesia. This training focuses on English for classroom use and student report writing. The training was conducted by two facilitators (the authors) in ten meetings. The main activities, six face-to-face in-class sessions, included syllabus presentations, discussions about teaching styles, sharing of teaching experiences and of various needs to meet especially to facilitate or accommodate some students with special needs, teaching demonstrations, and report writing. All of these activities were conducted in full English. Followup activities were in the form of one facilitators-participants conference in which the facilitators met each participant individually and discussed his/her progress in learning, two class observations in which the facilitators observed the participants teaching in their respective classes, and one discussion session with the curriculum coordinator about the progress of the participants during the training as an input for the school to determine the follow-up policy regarding the participants' professional development.
\end{abstract}

Keywords: Community service, English for classroom use, student reports

\begin{abstract}
Abstrak
Kegiatan pengabdian kepada masyarakat (PKM) yang dilakukan bertujuan untuk memberikan pelatihan Bahasa Inggris kepada guru-guru SMP/SMA Tumbuh Yogyakarta, Indonesia. Pelatihan ini mencakup penggunaan Bahasa Inggris secara lisan sebagai pengantar instruksi (kegiatan pembelajaran), dan penulisan laporan hasil belajar siswa. Pelatihan dilakukan oleh dua fasilitator (penulis) dalam sepuluh kali pertemuan.Kegiatan utama adalah enam sesi tatap muka di kelas yang berisi presentasi silabus, diskusi tentang gaya mengajar, sharing pengalaman mengajar dan berbagai macam kebutuhan khususnya untuk menfasilitasi beberapa siswa berkebutuhan khusus, demonstrasi mengajar, dan penulisan laporan hasil belajar siswa yang kesemuanya dilakukan dalam Bahasa Inggris. Kegiatan lanjutan berupa diskusi hasil belajar, dua kali observasi cara mengajar para peserta di kelas yang diampu, dan satu sesi diskusi tentang perkembangan para peserta dengan koordinator kurikulum untuk menjadi masukan bagi sekolah menentukan kebijakan lanjutan.
\end{abstract}

Kata kunci: Pengabdian kepada masyarakat (PKM), Bahasa Inggris sebagai pengantar instruksi, laporan hasil belajar

\section{PENDAHULUAN}

Guru adalah komponen penting dalam pendidikan siswa. Karena itulah, kualitas guru sangat erat kaitannya dengan kualitas pendidikan secara umum. Atas dasar itulah, guru selalu dituntut untuk mengembangkan diri mereka secara profesional. Tuntutan untuk meningkatkan kemampuan profesional guru juga dipengaruhi oleh 
tuntutan pekerjaan mereka di sekolah. Kultur dan visi misi sekolah mempengaruhi para guru yang ada di dalamnya, tak terkecuali para guru di SMP/SMA Tumbuh Yogyakarta.

Sesuai dengan informasi dalam laman Sekolah Tumbuh, SMP/SMA Tumbuh Yogyakarta adalah bagian dari Sekolah Tumbuh, suatu institusi pendidikan swasta terkemuka di Yogyakarta yang menyelenggarakan pendidikan formal mulai dari jenjang persiapan (usia 4-5 tahun), Sekolah Dasar (SD) (kelas 1-6), hingga Sekolah Menengah (SMP/SMA) (kelas 7-12) (Sekolah Tumbuh, 2019). Lebih jauh, Sekolah Tumbuh adalah sekolah inklusif yang menfasilitasisiswa untuk menjadi individu yang bangga pada potensi dirinya dan menghargai keragaman yang ada dalam masyarakat (Sekolah Tumbuh, 2019). SMP/SMA Tumbuh khususnya menerapkan semangat pendidikan untuk semua (education for all),memberikan penghargaan terhadap nilai-nilai perbedaan, dan bertumbuh dalam keberagaman, termasuk di dalamnya keberagaman agama, budaya, ekonomi, dan kebutuhan individu (Sekolah Tumbuh, 2019). SMP/SMA Tumbuh memiliki dua jenis program, program nasional, di mana instruksi (kegiatan pembelajaran) dilaksanakan dengan Bahasa Indonesia sebagai bahasa pengantar dan program internasional yang menggunakan kurikulum International Middle Year Curriculum (IMYC) untuk mata pelajaran IPA, Matematika, Ilmu Sosial (Sejarah dan Geografi), Teknologi Informasi dan Komunikasi (TIK) yang disampaikan dalam Bahasa Inggris (Sekolah Tumbuh, 2019).

Guna memfasilitasi para guru program internasional untuk dapat meningkatkan kemampuan berbahasa Inggris, Sekolah Tumbuh secara reguler mengadakan pelatihan Bahasa Inggris untuk para guru sesuai dengan bidang studi yang diampu. Program ini merupakan program tahunan yang sudah berlangsung sejak tahun 2017, namun kegiatan PKM ini adalah langkah awal kerja sama antara SMP/SMA Tumbuh dan Program Studi Pendidikan Bahasa Inggris (Prodi PBI) Universitas Kristen Duta Wacana (UKDW) dalam menyelenggarakan program tersebut. Kerjasama ini juga didasari kesadaran bahwa kualitas dan kapasitas guru berpengaruh besar terhadap kualitas pendidikan siswa. Dalam hal ini, dosen, apalagi dosen yang bekerja dalam Prodi Kependidikan seperti Prodi PBI, memiliki tanggungjawab moral untuk ikut andil dalam meningkatkan kualitas dan kapasitas guru. Hal ini juga dapat dilihat dengan banyaknya kegiatan PKM para dosen Prodi PBI dalam kegiatan peningkatan kapasitas guru (contoh: Pahmi et al., 2018; Syahfutra \& Niah, 2017). Pelatihan ini adalah wujud pengamalan Tridharma, yaitu pengabdian kepada masyarakat (Eniyati \& Noor, 2010; Setiaji \& Kurniawan, 2011).

Secara umum, pelatihan Bahasa Inggris yang diberikan oleh fasilitator dari Prodi PBI UKDW pada semester genap 2018/2019 ini memiliki target peningkatan keterampilan berbicara dan menulis para guru guna mendukung peningkatan profesionalitas mereka dalam mengajar di kelas internasional inklusif.

\section{METODE PENGABDIAN}

Sebagai langkah awal, dilakukan pertemuan antara fasilitator dengan koordinator kurikulum SMP/SMA Tumbuh untuk membicarakan kebutuhan pelatihan secara spesifik dan jadwal pelatihan. Hal ini didasari kesadaran akan pentingnya analisis kebutuhan (needs analysis) dalam 
perencanaan program/pelatihan bahasa (Nation \& Macalister, 2010). Dari hasil analisis kebutuhan, fasilitator merumuskan topik dan materi yang sesuai dengan kebutuhan. Dari hasil diskusi ditemukan bahwa para peserta memiliki kemampuan lisan Bahasa Inggris yang, meskipun relatif baik, masih perlu ditingkatkan, serta mereka belum terlalu mampu menulis laporan hasil belajar siswa dalam Bahasa Inggris secara lancar dan dengan variasi bahasa yang baik. Analisis terhadap kebutuhan ini sangat diperlukan untuk memfasilitasi kebutuhan para guru dalam usaha menjaga relevansi materi pelatihan dengan kebutuhan para guru peserta pelatihan (Richards, 2001) .

Perencanaan jadwal menghasilkan kesepakatan bahwa pelatihan akan dilaksanakan seminggu sekali pada hari Jumat jam 13.30-15.00, sebanyak enam kali tatap muka. Di samping itu, ada satu sesi penyampaian hasil dan kemajuan belajar peserta, dua sesi observasi di kelas, dan satu sesi laporan hasil observasi pembelajaran tiap peserta pelatihan. Total pertemuan sebanyak 10 kali, dimulai dari bulan Februari dan berakhir pada bulan Mei 2019.

Adanya sesi penyampaian hasil dan kemajuan belajar peserta didasari kesadaran bahwa peserta berhak mengetahui perkembangan belajar mereka secara transparan apalagi laporan ini juga akan diteruskan kepada atasan langsung mereka, yaitu Kepala Sekolah atau koordinator kurikulum. Dua sesi observasi diharapkan digunakan untuk melihat sejauh mana para peserta mengalami peningkatan atau perkembangan dalam kemampuan mereka secara kebahasaan setelah pelatihan. Sementara itu, laporan akhir kepada Kepala Sekolah atau koordinator kurikulum adalah media fasilitator untuk menyampaikan perkembangan para peserta baik dalam kemampuan lisan berbahasa Inggris dalam mengajar maupun kemampuan menulis laporan hasil belajar.

\section{HASIL DAN PEMBAHASAN}

Total dilaksanakan sebanyak 10 kali pertemuan, yang terdiri dari: enam kali tatap muka, satu kali penyampaian hasil dan kemajuan belajar, dua kali observasi proses pengajaran, dan satu kali laporan hasil observasi/laporan akhir. Pelatihan ini diikuti oleh enam peserta.

Agenda pertemuan pertama sampai dengan keenam berupa kegiatan tatap muka di kelas dapat dirangkum dalam Tabel 1.

\begin{tabular}{|c|c|c|}
\hline $\begin{array}{l}\text { Pertemuan } \\
\text { ke- }\end{array}$ & Hari/tanggal & Kegiatan \\
\hline 1 & $\begin{array}{l}\text { Jumat, } 8 \\
\text { Februari } \\
2019\end{array}$ & $\begin{array}{l}\text { Perkenalan } \\
\text { dan diskusi } \\
\text { lebih lanjut } \\
\text { tentang } \\
\text { kebutuhan } \\
\text { para peserta } \\
\text { secara } \\
\text { kebahasaan } \\
\text { (analisis } \\
\text { kebutuhan } \\
\text { lanjutan) }\end{array}$ \\
\hline 2 & $\begin{array}{l}\text { Jumat, } 15 \\
\text { Februari } \\
2019\end{array}$ & $\begin{array}{l}\text { Guru } \\
\text { melakukan } \\
\text { presentasi } \\
\text { silabus } \\
\text { dengan } \\
\text { Bahasa } \\
\text { Inggris } \\
\text { (dalam } \\
\text { konteks } \\
\text { seminar } \\
\text { silabus para } \\
\text { guru) }\end{array}$ \\
\hline 3 & $\begin{array}{l}\text { Jumat, } 22 \\
\text { Februari } \\
2019\end{array}$ & $\begin{array}{l}\text { Diskusi } \\
\text { bersama } \\
\text { tentang } \\
\text { permasalahan } \\
\text { di kelas dan } \\
\text { gaya }\end{array}$ \\
\hline
\end{tabular}




\begin{tabular}{lll} 
& & $\begin{array}{l}\text { mengajar } \\
\text { dalam Bahasa } \\
\text { Inggris }\end{array}$ \\
\hline 4 & Jumat, 8 & $\begin{array}{l}\text { Demonstransi } \\
\text { Mengajar } \\
\text { (bagian 1) }\end{array}$ \\
\hline 5 & Jumat, 29 & $\begin{array}{l}\text { Demonstrasi } \\
\text { mengajar } \\
\text { Maret 2019 }\end{array}$ \\
& (bagian 2) \\
\hline April 2019 & $\begin{array}{l}\text { Peserta } \\
\text { latihan } \\
\text { menulis } \\
\text { laporan hasil } \\
\text { belajar siswa } \\
\text { dalam Bahasa } \\
\end{array}$ \\
& Inggris
\end{tabular}

Pada pertemuan pertama, 8 Februari 2019, fasilitator dan peserta mendiskusikan agenda pelatihan dan topik yang akan dipelajari bersama, termasuk kebutuhan peserta sebagai guru mata pelajaran dan guru pendamping yang sangat berbeda. Peserta kemudian bersimulasi menghadapi berbagai macam skenario keadaan di kelas.

Di sini, fasilitator menemukan suatu tantangan. Ternyata salah satu peserta bukan merupakan guru mata pelajaran melainkan support teacher atau asisten pengajar yang bertugas mendampingi para siswa berkebutuhan khusus seperti penyandang hearing impairment dan autisme yang memang diakomodasi di SMP/SMA Tumbuh ini. Tugas dari asisten pengajar ini di kelas adalah memberikan bantuan kepada para siswa berkebutuhan khusus ini dengan melakukan interpreting tentang apa yang disampaikan guru mata pelajaran dan membantu menjaga konsentrasi para siswa berkebutuhan khusus ini sesuai dengan kebutuhan mereka masingmasing. Di sinilah fasilitator kemudian merancang aktivitas yang berbeda untuk asisten pengajar ini demi memfasilitasi relevansi aktivitas dengan kebutuhan (Richards, 2001).

Pada pertemuan kedua, 15 Februari 2019, masing-masing peserta mempresentasikan dalam Bahasa Inggris silabus mata pelajaran yang diampu sesuai dengan kurikulum yang dipakai SMP/SMA Tumbuh. Kegiatan pada sesi ini bermula dari keinginan besar para guru untuk dapat mempresentasikan silabus mereka dalam seminar silabus yang biasa dilakukan dalam rapat guru sebelum semester dimulai. Fasilitator membantu para peserta apabila mengalami kesulitan dalam kosakata dan pelafalan. Secara umum, para peserta mampu berbicara dalam Bahasa Inggris dengan relatif lancar dan berkesinambungan meskipun mengalami beberapa kesulitan terkait kosakata dan pelafalan dan tata bahasa yang seringkali tidak akurat.

Pada pertemuan ketiga, 22 Februari 2019, para peserta mengisi selfobservation form atau kuesioner evaluasi diri terkait cara mengajar mereka dan membagikan hasil refleksi mengenai pengalaman mereka dalam mengajar, misalnya: suasana pembelajaran, kebutuhan siswa yang beragam, adanya siswa berkebutuhan khusus, dan contoh kegiatan pembelajaran. Semua dilakukan dalam Bahasa Inggris. Para peserta juga banyak menyinggung dinamika mengajar para siswa berkebutuhan khusus yang juga membuat mereka semakin berkembang 
bukan hanya sebagai guru namun juga sebagai manusia. Kegiatan ini mendorong para peserta untuk menjadi reflective teachers, atau guru yang selalu/terus berefleksi tentang aktivitas keseharian dalam proses pembelajaran untuk dapat semakin meningkatkan kualitas dan kapasitas mereka dan efektivitas pembelajaran (Richards \& Lockhart, 1996; Williams \& Burden, 1997).

Pada pertemuan keempat, 8 Maret 2019, dan pertemuan kelima, 29 Maret 2019, para peserta melakukan demosntrasi mengajar dalam Bahasa Inggris sesuai bidang studi yang mereka ampu diawali dengan pengenalan topik, penyampaian topik bahasan, dan penutup. Fasilitator memberikan feedback (umpan balik) terkait kebahasaan. Fasilitator juga memberikan aktivitas ice-breaking yang memfasilitasi para peserta untuk banyak berbicara dalam Bahasa Inggris dalam suasana yang tetap santai(Chlup \& Collins, 2010).

Pada Gambar 1 dan Gambar 2 dapat dilihat peserta yang sedang melakukan demonstrasi mengajar dalam Bahasa Inggris.

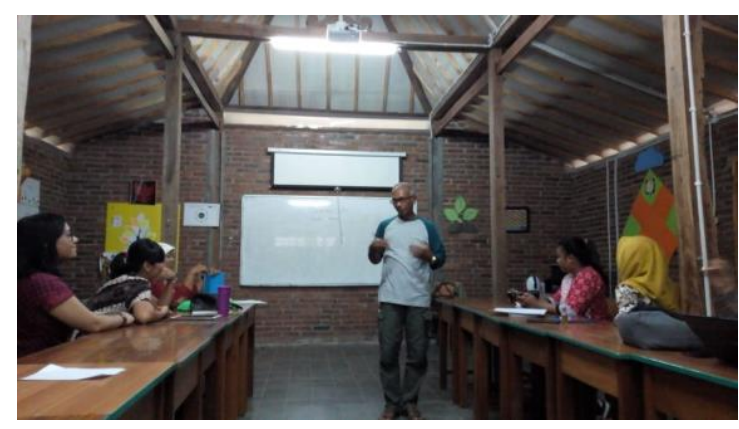

Gambar 1. Demonstrasi mengajar 1

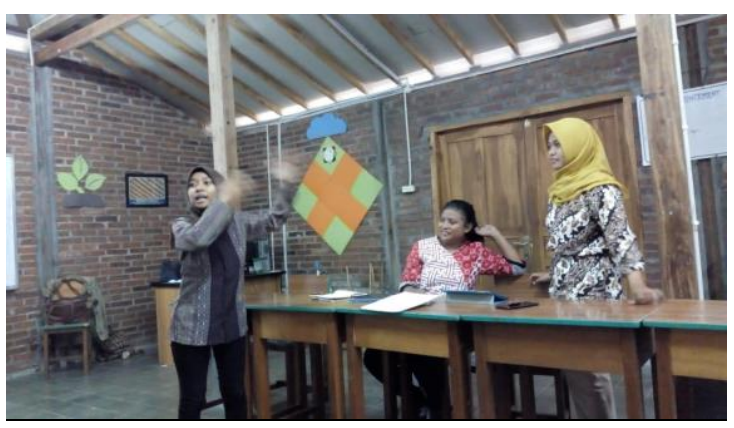

Gambar 2. Demonstrasi mengajar 2

Pada pertemuan keenam, 5 April 2019, para peserta berlatih menulis laporan hasil belajar siswa dengan terlebih dahulu menganalisis contoh laporan serupa yang kurang sempurna. Para peserta difasilitasi untuk dapat membuat laporan dengan gaya feedback sandwich, yaitu umpan balik yang berisi kombinasi hal-hal positif dan hal-hal yang masih perlu perbaikan dari siswa dengan cara yang psychologically motivating atau memberi pesan positif untuk perbaikan (Henley \& Reed, 2015; Yin, 2010).Pada Gambar 3, fasilitator memberikan pendampingan terhadap salah satu guru dalam menulis laporan hasil belajar.

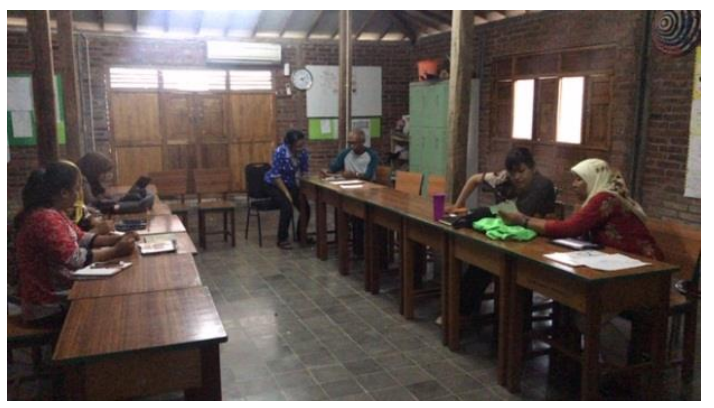

Gambar 3. Fasilitator mendampingi salah satu peserta (tengah)

Selanjutnya, agenda pertemuan ketujuh sampai dengan kesepuluh, berupa kegiatan observasi dan laporan hasil belajar, dapat dirangkum dalam Tabel 2.

Tabel 2. Kegiatan observasi dan laporan perkembangan dan hasil belajar 


\begin{tabular}{|c|c|c|}
\hline $\begin{array}{l}\text { Pertemuan } \\
\text { ke- }\end{array}$ & Hari/tanggal & Kegiatan \\
\hline 7 & $\begin{array}{l}\text { Jumat, } 12 \\
\text { April } 2019\end{array}$ & $\begin{array}{l}\text { Pertemuan } \\
\text { fasilitator dan } \\
\text { peserta untuk } \\
\text { mendiskusikan } \\
\text { proses dan hasil } \\
\text { belajar mereka }\end{array}$ \\
\hline 8 & $\begin{array}{l}\text { Selasa, } 30 \\
\text { April } 2019\end{array}$ & $\begin{array}{l}\text { Observasi } \\
\text { fasilitator di } \\
\text { beberapa kelas } \\
\text { yang diampu } \\
\text { peserta }\end{array}$ \\
\hline 9 & $\begin{array}{l}\text { Jumat, } 10 \\
\text { Mei } 2019\end{array}$ & $\begin{array}{l}\text { Observasi } \\
\text { fasilitator di } \\
\text { beberapa kelas } \\
\text { yang diampu } \\
\text { peserta }\end{array}$ \\
\hline 10 & $\begin{array}{l}\text { Selasa, } 14 \\
\text { Mei } 2019\end{array}$ & $\begin{array}{l}\text { Laporan akhir } \\
\text { fasilitator } \\
\text { kepada } \\
\text { koordinator } \\
\text { kurikulum }\end{array}$ \\
\hline
\end{tabular}

Pada pertemuan keenam, 12 April 2019, fasilitator bertemu dengan para peserta satu persatu untuk menyampaikan perkembangan belajar mereka dan masukan terkait simulasi/demonstrasi mengajar dan laporan hasil belajar siswa yang ditulis sebelumnya. Di sini, para peserta juga menyampaikankesulitankesulitan yang mereka alami sekaligus meminta saran fasilitator terkait kesulitan-kesulitan tersebut. Salah satu peserta, misalnya, menyampaikan bahwa kegiatan ice-breaking yang dipraktikan selama pelatihan pernah digunakan di kelas dan berhasil. Ini menunjukkan relevansi materi pelatihan terhadap kebutuhan.

Pada pertemuan ketujuh dan kedelapan, fasilitator melakukan observasi di kelas- kelas yang diampu para peserta. Para peserta secara umum menunjukkan kemampuan Bahasa Inggris yang baik di kelas. Tentu, seberapapun efektif pelatihan yang diadakan fasilitator, kemampuan para guru dalam berbahasa Inggris tidak bisa diatribusikan sepenuhnya dengan pelatihan ini, namun juga harus diatribusikan dengan pengalaman/jam terbang mereka dalam mengajar menggunakan Bahasa Inggris sebelumnya ataupun pelatihan-pelatihan yang mereka dapatkan sebelumnya sebagai suatu proses yang terus menerus. Gambar 4 menampilkan salah satu guru yang sedang mengajar di kelasnya, sementar Gambar 5 menampilkan asisten pengajar yang sedang membantu siswa berkebutuhan khusus.

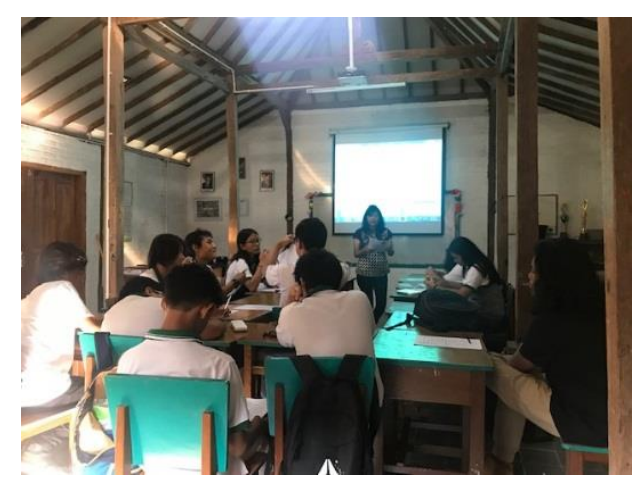

Gambar 4.Peserta mengajar di kelas

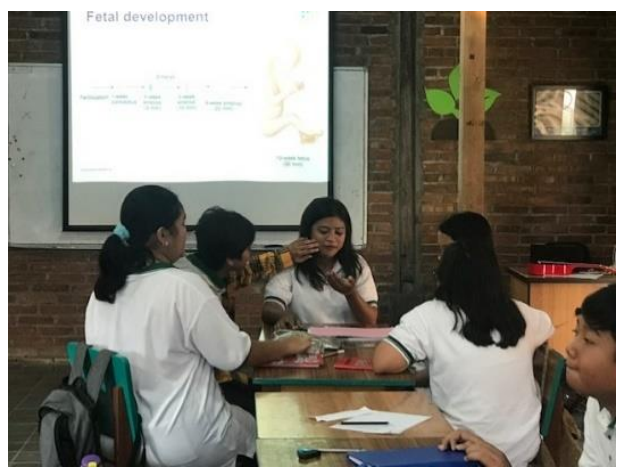

Gambar 5.Peserta asisten pengajar (tengah) membantu siswa berkebutuhan khusus 
Pertemuan terakhir dilakukan fasilitator dengan koordinator kurikulum. Sesi ini digunakan fasilitator untuk menyampaikan hasil monitoring, perkembangan, dan laporan akhir kegiatan pelatihan Bahasa Inggris. Terdapat pula diskusi terkait kemampuan serta perkembangan para peserta dalam penguasaan Bahasa Inggris

\section{SIMPULAN}

Terdapat beberapa kesimpulan terkait pelatihan ini.

1. Para peserta memiliki kemampuan Bahasa Inggris yang relatif sudah bagus sebelum pelatihan. Namun, pelatihan ini juga cukup berhasil dalam meningkatkan kepercayaan diri peserta dalam berbicara sehingga peserta yang tadinya agak malu dalam berbicara dapat lebih berani.

2. Pihak sekolah menilai kemampuan Bahasa Inggris para peserta harus terus diasah terutama kemampuan berbicara. Oleh karena itu, pihak sekolah berencana akan mengadakan pelatihan Bahasa Inggris di semester gasal 2019/2020 dengan materi IELTS speaking test dengan fasilitator yang sama

3. Yang tak kalah pentingnya adalah bahwa dari para peserta, fasilitator juga banyak belajar tentang suka duka memfasilitasi beberapa siswa berkebutuhan khusus untuk dapat berprestasi di dalam konteks kelas inklusif. Dari mereka, fasilitator juga belajar bahwa no child shall be left behind atau tidak boleh ada siswa yang tertinggalkan /ditinggalkan(Sheehy, Budiyanto, Kaye, \& Rofiah, 2017)

\section{UCAPAN TERIMA KASIH}

Terima kasih kami ucapkan kepada semua pihak yang memungkinkan terlaksananya kegiatan PKM ini. Pihakpihak tersebut adalah :

1. Ketua Program Studi Pendidikan Bahasa Inggris Universitas Kristen Duta Wacana

2. Kepala Sekolah Tumbuh

3. Koordinator kurikulum SMP/SMA Tumbuh Yogyakarta

4. Para peserta/guru SMP/SMA Tumbuh Yogyakarta

\section{DAFTAR PUSTAKA}

[1].Chlup, D. T., \& Collins, T. E. (2010). Breaking the ice: Using icebreakers and re-energizers with adult learners [Memecahkan kebekuan: Menggunakan aktivitas pemecah kebekuan dan penyemangat bersama pembelajar dewasa]. Adult Learning, 21(3-4), 34-39.

[2].Eniyati, S., \& Noor, C. (2010). Perancangan sistem pendukung keputusan penilaian prestasi dosen berdasarkan penelitian dan pengabdian masyarakat. Jurnal Teknologi Informasi DINAMIK, 15(2), 136-142.

[3].Henley, A. J., \& Reed, F. D. D. (2015). Should you order the Feedback Sandwich? Efficacy of feedback sequence and timing [Apakah kita harus pesan sandwich umpan balik? Kecukupan urutan dan ketepatan waktu pemberian umpan balik]. Journal of Organizational Behavior Management, 35(3-4), 321-335. [4].Nation, I., \& Macalister, J. (2010). 
Language curriculum design [Desain kurikulum bahasa]. New York: Routledge.

[5].Pahmi, P., Ardiya, A., Syahfutra, W., Wibowo, A. P., Niah, S., \& Febtiningsih, P. (2018). Pelatihan penggunaan Mendeley untuk referensi dalam menulis karya ilmiah bagi guru SMA Handayani Pekanbaru. Jurnal Pengabdian Untuk Mu NegeRI, 2(2), 35-39.

[6].Richards, J. C. (2001). Curriculum development in language teaching [Penyusunan kurikulum dalam pembelajaran bahasa]. Cambridge: Cambridge University Press.

[7].Richards, J. C., \& Lockhart, C. (1996). Reflective teaching in second language classrooms [Pembelajaran reflektif dalam kelas bahasa kedua]. Cambridge: Cambridge University Press.

[8].Sekolah Tumbuh (2019). Sekolah Tumbuh. Diambil pada July 8, 2019, dari https://sekolahtumbuh.sch.id/

[9].Setiaji, H., \& Kurniawan, R. (2011). Sistem informasi penelitian dan pengabdian dosen guna otomatisasi penentuan angka kredit dosen dan mendukung aktivitas tridharma perguruan tinggi. DalamSeminar Nasional Aplikasi Teknologi Informasi 2011 (SNATI 2011), Yogyakarta 17-18 Juni 2011 (pp. 92-98).

[10]. Sheehy, K., Budiyanto, B.,
Kaye, H., \& Rofiah, K. (2017). Indonesian teachers' epistemological beliefs and inclusive education [Keyakinan epistemologis guru-guru Indonesia dan pendidikan inklusif]. Journal of Intellectual Disabilities, $X X(\mathrm{X})$. https://doi.org/10.1177/174462951 7717613

[11]. Syahfutra, W., \& Niah, S. (2017). Menguasai speaking skill Bahasa Inggris dengan konsep English Day bagi guru dan karyawan di SMA Islam Terpadu Fadhilah Pekanbaru. Jurnal Pengabdian Untuk Mu negeRI, 1(2), 49-54.

[12]. Williams, M., \& Burden, R. (1997). Psychology for language teachers[Psikologi untuk pengajar bahasa]. Cambridge: Cambridge University Press.

[13]. Yin, M. (2010). Understanding classroom language assessment through teacher thinking research [Memahami asesmen kelas bahasa melalui riset tentang pemikiran para pengajar]. Language Assessment Quarterly, 7(2), 175-194. 